\title{
Tobacco Industry Changing Lives: Women Workers at the Turn of the $20^{\text {st }}$ Century
}

\author{
TAMARA NIKOLIĆ ĐERIĆ \\ Ethnographic museum of Istria, Pazin
}

\begin{abstract}
Tvornica Duhana Rovinj (TDR) - the Tobacco Factory in Rovinj is one of the first industrial plants in modern Croatia. More than a century-old tradition of cigarette production has enabled the TDR to impose itself on the world market and to continue its successful business. TDR has also established a particular cultural and social identity transmitted by its workers, the Tabacheine (women workers) in particular. In 1872 the decision had to be made whether the factory should be built in Koper (modern Slovenia) or Rovinj. An abundant female labour force was the crucial reason why the factory was built in Rovinj. Ever since then, women's everyday life has been turned upside down. High wages and respectability achieved by working in the Factory have, for all intents and purposes, created a new social group. Men were not the exclusive providers for the family and they also lost their exclusive right to choose their spouses. Based on historical documents and interviews with interviewees from Rovinj and its surroundings, the paper retraces the development and changes in this small community; ethnic, social and gender differences generated by the development of a specific industry which is situated into a larger social and historical context enabling comparison with other societies involved in cigarette production. Thus the aim of the paper is to detect possible cultural and social patterns or unique examples of women's emancipation. Furthermore the paper traces the significance of different aspects of remembrance, pointing to possibly idealized visions of the past.
\end{abstract}

Key words: industrial anthropology, tobacco, women workers, standpoint theory

\section{INTRODUCTION}

I was born and raised in Rovinj, a city marked by the tradition of cigarette making. I still remember the smell in the streets and the occasional sea pollution in front of the Factory. I write Factory with a capital F since the Factory has always been perceived as a gift to the local community, especially women. It still is a gift for many, although thanks to modern mechanisation, the "tables" have been replaced by "trails", the Factory no longer has an 
almost exclusively female workforce and the plant has been moved $16 \mathrm{~km}$ from Rovinj, leaving the Austro-Hungarian building to live a new life serving the tourist industry.

As an ethnologist and cultural anthropologist pursuing my $\mathrm{PhD}$, I started to think about the women of Rovinj and the almost mythical role they played in modern history and in the memories of a small coastal town whose economy had earlier been connected almost exclusively with the sea. Ethnological in methodology and anthropological in a wider interpretative space, partly based on historical accounts, the paper traces social relationships lived by our (great)-grandmothers and inherited values established through these relationships. Nevertheless, I also base my research on present perspectives of a past time and remembrance.

The prevailing opinion is that women of the Mediterranean cultural area occupied a second rate position in society. Excluded from activities in public life, on the whole they were pushed aside to devote themselves to activities in their homes. Fernand Braudel considers, moreover, that the evident attachment of women of the Mediterranean area to their households is a civilisation-fact of particular significance. (Muraj 1996: 135)

In her work Muraj also points to ambivalent positions of women in the Mediterranean, showing that different social and historical conditions shape women's status in a non-linear mode (ibid.).

Universalist ideas, as is the one mentioned above, which "appeared in the 1970s considered that male dominance is a universal fact throughout all societies and all aspects of human life" (Škokić 2004: 20). Moreover, the hierarchized men-women relationship saw women as dedicated to the household, children and education, therefore associated to the private space of the house while men, on the other hand, "represented" the public, social life (ibid.). Historical documents and present testimonies speak about a slightly different position of women in Rovinj. Even though they worked at home and were excluded from public life in general, if historical accounts ${ }^{1}$ are to be believed, their position was far from oppressed. Taking this into consideration along with the mentioned insights by Muraj and Škokić, I would suggest considering a "subject that is fundamentally connected to the social setting and, indeed, constituted by that setting - an embedded, encumbered, or embodied subject" (Hekman 1992: 1100).

Although many questions will be raised throughout this work, the main points of the paper are: Is it possible to speak about economically-driven

\footnotetext{
${ }^{1}$ Bernardo Benussi Storia documentata di Rovigno (1888).
} 
emancipation, using Rovinj women workers as an example; and, secondly: Were these women really privileged or is it just a romanticized vision that the local inhabitants have been perpetually reproducing for over a century.

The anthropological space is (thus) inevitably historical as it is inhabited by human groups; in other words it is a symbolic space. (Augé 1999: 13)

Following Augé's insights, the scope of ethno-history is to explore the significance of different aspects of remembrance; to learn how to read tacit, forgotten or distorted genealogies, and to evaluate the real role and ideological function of an event magnified by tradition (ibid.: 19).

Rovinj's tobacco workers are still a symbol of Rovinj, always represented in quite luxurious dresses and remembered as the wealthiest social stratum of Rovinj. The paper aims at demystifying this general and simplified vision. Is this enterprise attainable for a "native" anthropologist marked not only by this inherited vision of prestigious women-workers but also by the fact of being a woman? Will my professional background and theoretical approach concerned with the feminist critique of androcentric production of knowledge and oppressed status of women in general, be a burden in researching and interpreting women workers? Writings regarding the position of native anthropologists or insiders have already critiqued the dichotomy between the native and non-native anthropologist.

Arguing that because a culture is not homogenous, a society is differentiated, and a professional identity that involves problematizing lived reality inevitably creates a distance, scholars such as Aguilar (1981) and Messerschmidt (1981a) conclude that the extent to which anyone is an authentic insider is questionable ...Instead, what we must focus our attention on is the quality of relations with the people we seek to represent in our texts... (Narayan 1993: 671-672)

Moreover, to write about women workers at the end of the $19^{\text {th }} /$ the beginning of the $20^{\text {th }}$ century and today's perspective on this subject open up new challenges. Not only were women excluded from the public life, they were also often excluded from historical accounts and, what is more important, there are no female writings that could serve as an alternative to the predominant male perspective. "In the history of scientific discourse the male perspective was actually a positivistic episteme to which objectiveness and neutral positions were ascribed" (Škokić 2004: 17). Today's alternative may be found in various feminist theories and methodologies, among 
them the standpoint theory ${ }^{2}$ and the concept of subjectivity, ${ }^{3}$ which partially represents a personal "strategy" in achieving the main goal of this work: an account of Rovinj women workers distanced from idealized visions but fully respective of the memories and perceptions my informants shared in the research process. Referring to Narayan once again "prejudiced forms of representation", can be replaced with the acceptance of "more experiential and affective modes of knowing" in which the ethnographer's identity and location are made explicit and informants are given a greater role in texts. This is what Michael Jackson (1989) more recently called "radical empiricism" a methodology and discursive-style that emphasizes the subject's experience and involvement with others in the construction of knowledge (cf. Stoller 1992)" (Narayan 1993: 680).

\section{THE PROCESS OF INDUSTRIALIZATION AND ITS SOCIO-HISTORICAL CONTEXT IN ROVINJ}

According to historical sources, ${ }^{4}$ the earliest branch of industry in the Rovinj area was stone quarrying. The people of Rovinj had been renowned stonemasons since the $13^{\text {th }}$ century and there are numerous documents describing the excellent quality of stone that was used in the construction of buildings throughout the present-day Italy. Apart from fishery, seafaring and agriculture, shipbuilding started to develop gradually. However, at the time when Bernardo Benussi was writing (1888) the key piece on social and historical situation in the Rovinj area, shipbuilding was already stagnating and the author recalls numerous shipyards that had already disappeared. About a hundred years before the establishment of the Factory, in 1780, 3,670 persons were dedicated to various production activities, from crafts, trading and seafaring to farming and serving (Benussi 2004: 144-145). At the end of the $19^{\text {th }}$ century, Rovinj was a major trading and industrial centre. The

\footnotetext{
2 "Standpoint theories argue for 'starting off thought' from the lives of marginalized peoples; beginning in those determinate, objective locations in any social order will generate illuminating critical questions that do not arise in thought that begins from dominant group lives. Starting off research from women's lives will generate less partial and distorted accounts not only of women's lives but also of men's lives and of the whole social order. Women's lives and experiences provide the 'grounds' for this knowledge, though these clearly do not provide foundations for knowledge in the conventional philosophical sense. These grounds are the site, the activities, from which scientific questions arise" (Harding 2004: 128). "Feminist knowledge has started off from women's lives, but it has started off from many different women's lives; there is no typical or essential woman's life from which feminist start their thought" (ibid.: 134).

${ }^{3}$ In the spirit of the Postmodern discourse, which is "experimental, intersubjective and dialogic" (Škokić 2004: 22), I introduce the concept of subjectivity as part of the strategy of considering the given subject, stating at the same time my own position as well as the advantages and limitations this position may bring about.

${ }^{4}$ In Bernardo Benussi Storia documentata di Rovigno, 1888, Trieste.
} 
year 1847 saw the start of a mill and a pasta factory, in 1852 a cement and hydrated lime factory was opened, then in 1878 a wax factory. By the year 1886 there were also a soap factory, 6 olive oil extraction mills, two textile manufacturing workshops, a biscuit factory and a fish processing factory. The Tobacco Factory was opened in 1872. The Factory represents a significant turning point in the industrial and socio-cultural history of Rovinj, greatly due to the fact that it employed mostly women. Upon the insistence of the Mayor of Rovinj at the time, Matteo Campitelli, and based on the proposal of the State Counsellor Merkl von Reinsee, in 1872 the Imperial-Royal Ministry of Finance decided to establish the new processing plant in Rovinj. The first plant was opened under the name of "Tvornica Cigareta" (Cigarette Factory) in a small building at St. Damien's Square. Owing to its remarkable productivity, as early as the 15 September 1875 the independent complex built on the seacoast with its own water supply and drainage systems as well as electrical energy and steam production plants was inaugurated (Bosazzi 2012: 192). The date of the inauguration is indicative in itself, as on the $16^{\text {th }}$ of September Rovinj celebrates the Feast of Saint Euphemia, the town patron saint, one of the few female saints among patrons of towns. It is worth mentioning that Rovinj had to compete with Koper (modern Slovenia) concerning the establishment of the Factory and that the fact that there were more unemployed women in Rovinj was decisive in favouring Rovinj (Vlajo 1999: 36). Benussi stressed that the Mayor was especially involved in advocating the opening of the Factory in Rovinj precisely because of the large number of poor women or women who could acquire property only by farming (Benussi 2004: 235). 700 young women applied for work but only a part of them actually got a manufacturing job in the Factory. In 1873, 401 people were employed by the Rovinj Tobacco Factory, 391 of which were women. The disturbing fact was that this one third of the workforce were girls younger than 14 , although Austro-Hungarian legislation forbid employing children under that age. The limit was raised to 18 during the Italian government. Nevertheless, in his work on coal miners in Istria, Matošević argues that the living conditions were so poor that people falsified documents so as to prove their children were older and could start working (Matošević 2011: 226).

From its early days until the end of WW1, the Rovinj Factory was part of the Austro-Hungarian Tabak-regie, a state monopoly concentrating the overall tobacco processing and marketing in the territory of the Empire. In 1879 the Factory was producing 28,874,000 cigars and 3,853,000 packages of tobacco for smoking. Some time later, the production of cigarettes commenced when cigarette smoking was becoming fashionable all around Europe (Bosazzi 2012: 193). Despite the fact that the Rovinj Factory was just a small wheel in the tobacco industry machinery, it would seem that it was of great importance for the state treasury (Goluža 1997: 6-8). During WWI, the 
Factory discontinued production owing to, among other things, the fact that the majority of the population was taken to Austrian refugee camps.

One of the informers remembers:

My grandmother on my mother's side was employed in the Factory just before the beginning of WWI. Soon the Factory was closed up, partly also owing to forced displacement of Istrian Italians requested by the Austro-Hungarian Empire. My mother was born in appalling conditions in a village near Brno in 1916. My father was born in the same year, but in a hospital in Graz since his family was much better off and could afford accommodation in Graz. After giving birth, my grandmother on my father's side was visited by the archduchess Zita of Bourbon, who was visiting the hospital, and, being Italian by origin, she congratulated my grandmother in very good Italian. On that occasions all new mothers were given $6 \mathrm{~kg}$ of flour each, which was quite a lot at that time! ${ }^{5}$ (A. R.)

In February 1919 the Italian government reinstated production. Following the definite transfer to Italian jurisdiction, the Factory became part of the Monopoli di Stato italiani (Italian State Monopoly). Apart from being an important source of income that was otherwise difficult to earn, the Factory gave its workers access to numerous social benefits such as the day care centre, health care and leisure activities which reached their peak in the 1930s (Bosazzi 2012: 194). Employment in the factory also played a prominent role in the socialisation among women. Male and female workers would often organise charities, participate in different recreational activities, but also strikes; for instance, in 1894 female workers rose against the erection of bilingual signs in Piran and Rovinj, and went on solidarity strikes during the great strikes in the period of 1919 - 1921.

The post-war hardships were overcome quite quickly, and as early as in 1923 the Factory achieved the level of pre-war production, employed 840 people and opened 3 drying kilns in the Rovinj suburbs as well as small tobacco plantations in Sv. Petar u Šumi and Bale. Yet another change of political government in 1945 represented another turning point, not only in terms of organisational structure, mechanisation and market of the Factory, but also in terms of organisational culture and its ethnic image. Self-government as

\footnotetext{
${ }^{5}$ La nonna materna C. fu assunta in Fabbrica Tabacchi poco prima dello scoppio della prima Guerra Mondiale, poi ci fu l'interruzione del lavoro per l'internamento forzato degli italiani d'Istria voluto dall' Austria-Ungheria, durante il quale mise al mondo mia mamma, in una situazione miserabile in un paesino della Boemia vicino a Brno, nel 1916. nLa nonna paterna A., visto che era permesso, a chi ne aveva i mezzi, di trovare una adeguata sistemazione, partorì il mio papà sempre nel 1916, ma in ospedale a Graz, e ricevette anche la visita della consorte dell'erede di Francesco Giuseppe, Carlo, arciduchessa Zita di Borbone -Parma che, in visita in corsia, di nascita italiana quale era, si congratulò per il bel bambino in ottimo italiano, regalando poi a tutte le puerpere un sacchetto con 5 chili di farina, che nel '16 non era cosa da poco! (A. R.).
} 
a new way of management, shock-working ${ }^{6}$ as the working principle with a strong ideological background along with intense migration activities introduced deep changes into the everyday life of Rovinj, and they form the basis of the modern social image of the Town. Girls (of Slavic origin) from the rural parts of Istria were being employed in the Tobacco factory, which was practically impossible before; also being employed were inhabitants from other parts of Yugoslavia who were coming to Istria in search of jobs. The Yugoslav administration generated stronger ethnic diversification. The present faze of Rovinj's multiculturalism was created in the early 1950s. The first post-war years witness difficulties for local inhabitants in adapting to the new circumstances, especially in terms of language and new cultural and ideological patterns.

\section{WOMEN STATUS PRIOR TO AND AFTER THE ESTABLISHMENT OF THE TOBACCO FACTORY}

Even if it cannot be told with utmost certainty whether women took part in production processes prior to the end of the $19^{\text {th }}$ century and fast-paced industrialisation, the descriptions of such activities (always written using the male gender) lead us to the conclusion that women were not represented in the labour force in the social segment, but were confined to act within the four walls of their family houses. Unlike women on the eastern Adriatic coast, the women of Rovinj did not take part in fishing activities, e.g. shell fishing, and only a few of them would work in the "kampanja" (field) helping with farming jobs. ${ }^{7}$ Benussi mentioned women only when speaking of the population in general. He mentioned their character, listed the contents of their dowry and gave a detailed description of their clothing, in particular after the Venetian luxurious style had become popular among the women of Rovinj. Based on Benussi's opinion, the rise in clothing luxury marked a parallel decline in morals, without any further explanation. Moreover, the author of Storia documentata di Rovigno quoted an "important" testimony of the priest Tommasini, who recorded that the women of Rovinj were pretty (Benussi 2004: 173). The status of women started to change after the opening of the Rovinj Tobacco Factory. In his works Benussi himself included women into the Rovinj economy, thus also including them into the area of

6 "Shock-working" is a Soviet term used for "super productive" workers, who initiated highly productive and enthusiastic work. The concept was introduced in the Socialist Yugoslavia and it assumed new methods of work marked by competitiveness among workers as its core principle (more in Matošević 2011: 184-211).

${ }^{7}$ M. B. (born in 1954). 
public life. He gave them importance and removed them from the representational model of women as housewives who, apart from household chores, thought of nothing but brocade and silk from Venice. Another extreme in the presentation of Rovinj women before the onset of the Factory was connected with religiosity and the Church. Nevertheless, certain statements point to a relatively favourable status of women even before industrialisation, but it is worth mentioning that such status was always limited to their private lives. The Rovinj society thus practiced the so called "brak na istarski način" (Istrian Marriage Pattern). The Istrian Marriage Pattern as a rule defined the disposition of the property of the spouses, both the one "brought into" marriage and the one acquired during marriage. This marriage pattern was first mentioned in some $13^{\text {th }}$ century documents, mostly originating in the north of Istria, but became more widespread later. Upon the death of a husband, the Istrian Marriage Patter left the wife better protected than in the case of e.g. the Venetian Marriage Pattern (Mogorović Crljenko 2006). Benussi considered it useful and just, taking into consideration "hardships endured and the abilities of women" and added that women were also entitled to their share in family assets because they very often ran the household and also took care of the husband and the children (Benussi 2004: 177).

Girls would marry rather late, which can imply a certain maturity, but also freedom in the choice of a spouse. Thus, for example, according to the information dating back to 1880 , marriages were most often (54\%) entered into between men aged 24 to 30 and women aged 20 to 24, or between men aged 30 to 40 and women aged 24 to 30 (ibid.: 8). This data refers to the years after the establishment of the factory, which leads to the conclusion that the acquired financial stability also provided women with more freedom and, consequently, the position to choose a husband but also to remain single, to a reduced load of household chores and to the ownership of movables (mostly gold) and real estate (houses). ${ }^{8}$ Another informant's statement points to a change in arranged marriages after the assumed changed in women's status.

The women of Rovinj, who worked in the Factory, would walk with their head held high; they had enough means to cover their own needs, but also for a rich dowry thus becoming much desirable brides. Consequently, they claimed the right to choose their husbands, avoiding in this way to be forced into an arranged marriage as was customary at that time. (A. R.) ${ }^{9}$

\footnotetext{
${ }^{8}$ As per the statements of D. Q. (born in 1947), M. G. (born in 1935) and R. C. (born in 1930).

${ }^{9}$ A Rovigno la popolana che lavora in fabbrica cammina a testa alta, ha i mezzi per curare maggiormente la sua persona, mette da parte il necessario per la sua dote di futura sposa e diventa una fidanzata molto appetibile! E si arroga il giusto diritto di scegliere, aggirando i maneggi delle famiglie per combinare matrimoni, come si usava all'epoca. (English translation provided by the author).
} 
The standing given to women by their wealth made them equal members of society, at least judging from the statements given by female interviewees and Benussi's account, which was no small thing by any means. However, this was a far cry from equal participation in the town council and other management positions. Moreover, such an ideal picture was not always the rule. There were many women who sustained whole families on their factory wages. ${ }^{10}$

Granny C. used to emphasize that a constant and steady income earned by working in the Tobacco Factory directly helped the economic situation of her family. Grandfather A. was a fisherman, his income was expectedly uncertain since the catch of fish depended on the weather and current conditions at the fish market. The same fate was shared by farmers. Small land owners who worked for themselves were in a better situation. However, for women a job in the Factory was a godsend. Granny told me how her quindisina in Austrian crown was sufficient to feed two people, meaning that life was much more difficult for families with children and they had to manage the best they could. ${ }^{11}$ (A. R.)

The Tobacco Factory was a new source of previously inaccessible financial income, but it also meant hard work. As mentioned before in the text, the availability of a considerable female workforce and the entrepreneurial spirit of the Rovinj people, often mentioned by Benussi, turned the odds in favour of opening of the Factory in Rovinj. Even though the company newsletter reads that the jobs were easy which was why primarily women were employed, it is possible that women were better suited for this kind of work, because initially it was all manual labour. I come to this potential conclusion following the following thoughts by one of my informants:

The process of cigar making included selecting a nice, unspoiled leaf of tobacco which had to be filled with tobacco, rolled into a cylindrical form and closed with a small quantity of glue. It would be sharpened with a cutter and put into a slot in a box which was used to make the length and diameter of

\footnotetext{
${ }^{10}$ L. M. (born in 1928).

${ }^{11}$ Proprio a questo proposito la nonna C. rimarcava come avere l'introito sicuro e costante del lavoro in Fabbrica Tabacchi aiutasse, in maniera assolutamente dirimente, l'economia della sua famiglia. Il nonno A. faceva il pescatore, e gli introiti di quella categoria logicamente erano assolutamente aleatori, dipendendo il guadagno sul pescato sia dal maltempo che dalle stagioni che dal mercato del momento. Parimenti nelle famiglie dove l'uomo era contadino (sapadùr) era altrettanto aleatorio. Andava meglio per le famiglie dei piccoli proprietari di terra, che lavoravano sul proprio, comunque per la donna di casa il posto in Fabbrica era sempre una manna del cielo. Nonna C. mi diceva che la sua quindicina, in corone austriache, bastava per vivere in due, allora le esigenze di una famiglia di quello strato sociale erano peraltro modestissime, se c'erano figli era più difficile e bisognava arrangiarsi come meglio si poteva. (English translation provided by the author).
} 
the product uniform. It took sharp vision and skilful female hands for this repetitive job. ${ }^{12}$

On the other hand, men were involved in warfare, agriculture and fishery, and a ten-hour long involvement in the Factory was never an option. Of course, women were still busy doing household chores, bringing their working hours to eighteen, particularly in the period before Italian government, when fixed working hours were introduced in line with European laws. Before leaving for work, some lighter household chores had to be done, children had to be prepared for school and the day had to be organised. After work they would do the shopping and clean the house, sometimes stealing a few moments for themselves. The antagonism among female workers of different origin also affected the perception and evaluation of the work of the Rovinj women. While a successor of a Rovinj family said that the women of Rovinj were very industrious and could find balance between work in the factory and work at home, migrant workers often said that the Rovinj women were "princesses" who, owing to their financial stability, enjoyed assistance of others (in the household) and were not as skilful in household chores as women from rural areas coming to Rovinj. These picturesque statements further confirm the stereotypical images of workers, which were built in parallel with the workers' identities as belonging to the two major groups, but also confirm the oppressed position of migrant workers and their resistance strategy.

According to the employees' ledgers kept by the Tobacco Museum in Rovinj, the first women workers of the Tobacco Factory were Maria Longo (née Carlevalis) and Maria Devescovi (née Abba). Of the 401 workers, only 10 were men, but they held managerial or machinery maintenance positions. There were two places of work: the Factory, housing cigar production, was located at what were the outskirts of the town; a bit further there were barake (sheds), wooden structures at the far outskirts, used for storage and drying of tobacco. The wages, which would turn women into eligible brides, were received every fortnight and were therefore called quindisina. ${ }^{13}$ The Fascist government introduced numerous changes in the contexts of

${ }^{12}$ Il procedimento di confezione del sigaro prevedeva la scelta di una foglia che fosse bella, intatta e priva di costolature, da riempire con il tabacco e poi arrotolata a formare un cilindro affusolato e chiusa con una piccola quantità di colla. Poi veniva spuntato con il trancino e messo in una scanalatura della scatola, che aveva lo scopo di uniformare la lunghezza e il diametro del prodotto. Occhio acuto e dita agili delle donne, per un lavoro ripetitivo. (English translation provided by the author).

${ }^{13}$ From Ital. quindici $=$ fifteen 
protection of motherhood; for instance the factory day care centre (referred to as cunambulo in the Rovinj dialect) was opened, where women could leave their children from the youngest age. One of the interviewees ${ }^{14}$ said jokingly that she started her career right in the day care centre since she, following in her mother's and her elder sister's footsteps, also worked in the Tobacco Factory. The day care centre was based on a self-governing model; some of the workers took care of the children in shifts. An interviewee showed me a picture from 1943 showing her at the age of 2 standing next to her mother, who was working her shift in the day care centre, holding another child in her arms. "It was a matter of honour not to take your own child into your arms during work!" she explained. ${ }^{15}$

The prestige that was acquired by being employed at the Factory was described by one interviewee ${ }^{16}$ who remembered her father's story. He would wait in front of his cobbler shop for the Tabacheine to exit the Factory and go past his workshop. He hoped that his future wife, a girl he fancied at the time, would go past him and maybe return his glances. When the Tabacheine would exit the Factory, young men would often sing a song that spoke of their wealth and the quindisina, thus showing their admiration, courtship and desire to marry.

\section{E ciume ciume}

Son tabacheina

La quindisina I ta darie, ${ }^{17}$

(folk song)

Nevertheless, the Tabacheine often married foreigners, financiers and officers from Pula, Trieste..., and there were those who chose to remain single all of their life. This situation and a considerable inflow of new town women from the surrounding villages made mixed marriages a regular occurrence. Girls of Slavic origin from the surroundings of Rovinj, even though they could only get worse jobs (e.g. in the Ampelea fish processing factory) and did not enjoy the same prestige as the Tabachine, were able to earn money which was not easily accessible at the time, but could also find temporary accommodation, especially after World War 2 when the organisational and managerial structure in the factories changed. One of the interviewees ${ }^{18}$ pointed out that when she came to Rovinj she found a job at the Mirna Fish Factory and was

${ }^{14}$ D. Q. (born in 1947)

${ }^{15}$ Era un punto d'onore, durante l'incarico, non prendere in braccio il proprio! (English translation provided by the author).

${ }^{16}$ R. C. (born in 1930).

17 "Merry me, merry me, I'm a tabachina, I'll give you my quinisina (salary)" (translated by the author).

${ }^{18}$ M. G. (1935). 
also given a town-owned flat for use. Two years later she married a Rovinj man of Italian origin. The same interviewee emphasized that the women of Rovinj often mistreated the incoming women, considering them as inferior, one of the reasons also being the fact that they could not speak the Rovinj dialect or the standard Italian language.

The impossibility to find a job in the Tobacco Factory for such girls was confirmed to me on a number of occasions. ${ }^{19}$ One of the interviewees warned that employment policy was this way from the very beginning. Allegedly, women would follow generation by generation, a daughter would replace her mother, which was the best guarantee to achieve the highest level of honesty of the employees according to the factory administration at the time. The situation did not change until after the Second World War, but the intolerance could nevertheless occasionally be felt. The development of a specific industry, which discriminates women on the grounds of their origin when finding employment, creates a fertile ground for the emergence of different social identities, both in terms of class and gender. Thus the female labour force of a single town creates separate identities based on national and economic grounds. Significant differences could be felt between the Tabachine and the women working at the fish processing factory. These were the two major plants which offered a sufficient number required to develop dominant identities. While the Tabachine were nicely dressed and smelled of tobacco, the workers of the Mirna fish factory earned wages which were lower and depended on the fish catch. They worked outside with wet hands even during winter. As an interviewee ${ }^{20}$ pointed out, they reeked of fish and often felt uncomfortable passing through the town on their way home after a long-day's work. The several examples mentioned before give us only an introduction into the complexity of changes in Rovinj during the industrialization. Nevertheless, they present sufficient material proving the importance of women in the economic and social progress of Rovinj, the significance of industry for the emancipation of women and, finally, the mechanisms which created various and complex sociocultural identities of women workers in the Rovinj industrial plants. Furthermore, I believe that the provided examples are sufficient to develop the thesis that economic independence of women fosters emancipation, initially on the private level, and then on the social one, considering that the Tabachine were recognized as the economic power of Rovinj in the literature as early as the $19^{\text {th }}$ century. ${ }^{21}$

\footnotetext{
${ }^{19}$ M. G. (1935), D. Q. (1947), M. I. (1930), A. R. (1941).

${ }^{20}$ M. G. (1935).

${ }^{21}$ Benussi, Bernardo Storia documentata di Rovigno, Trieste, 1880.
} 


\section{ECONOMICALLY DRIVEN EMANCIPATION}

In her work Karen Sacks examines Engels's assumptions about the social position of women that he, rightly, considers different depending on the society or culture dealt with, and depending on the economic and political relationships within a community. Engels presents a historical overview of the transformation of women from free and equal members of society into oppressed wives. He believes the reason for this transformation to be private property ${ }^{22}$ which, for various reasons, passes into the hands of men. The ownership of land and/or domesticated animals marks the end of production exclusively for private use (use value), as the surplus of goods available is exchanged (exchange value). In this way women's work within household becomes marginal and less valued in the eyes of society (see Sacks 1975: 211-234). It was private property that, in the case I am dealing with, largely belonged to women, inducing us to consider its impact on the social and family status of women workers. When speaking of women workers in the tobacco industry, private property at that time meant available financial resources which women used to buy gold and, as was often the case, real estate. It is important, and Engels highlights the same point, to take into consideration that economic stability does not always guarantee emancipation, as was proven in the case of women tobacco workers in Thessaloniki over the same period in history that I am referring to. The tobacco industry there employed young Jewish women. Jobs were seasonal and were carried out sitting on the floor, referred to as embasho ${ }^{23}$ in the Ladino language, which had a certain negative connotation (Hadar 2007: 129) ${ }^{24}$ This position could be compared to experiences lived by women working in the fish processing factories. In these cases women were involved in industries and employments which were socially undervalued and of low income. Additionally, Hadar concluded that in a society where women are expected and assumed to achieve realization through family life, working in a factory was just a necessary evil. In their interviews conducted fifty years after the period spent working in the tobacco industry and fighting for female rights, the women did not recollect any progress, but only hours of arduous work (ibid.: 141).

This work gives an alternative view to the general picture of oppressed women workers and citing Weeks, brings an encouraging starting point for further research of working women:

${ }^{22}$ It is important to stress that the idea of private property is used in its widest sense. Only goods with productive potential are considered private property; Engels is aware of the fact that people owned personal items even before (Sacks 1975: 215).

${ }^{23}$ Embasho = lower. The term has negative connotations; the word basho means to be inferior, without education and honour.

${ }^{24}$ Nikolić Đerić (2011). 
"women's work" is not just an instance of women's oppression and exploitation, it is also a site where alternatives can be constructed; women's labouring practices are not only constraining, but also potentially enabling. (Weeks 2004: 187)

The research proposed by this paper points to great diversification of women labour. Although only a few gained wealth and an active social life, in general, the Rovinj tobacco workers saw employment as a gift; a possibility to acquire goods, to feed children, to gain equal rights at least in the sphere of family life and to do something for themselves especially in the context of leisure and avoiding arranged marriage. Listing the achievement of these elementary rights, I believe that along with the proposed analysis, the local imaginary connected with wealth and power can be enclosed in an urban myth. Nevertheless it is evident that the industrialization processes had a major influence on the emancipation processes of women in Rovinj.

The situation in Rovinj was not that common; in general literature and historical accounts women were excluded from industrialization processes even though they made a crucial part in its development. Bringing forth many examples from Britain, where women were banned from entering coal mines due to moral reasons, or Bolivia where folk believes, also eroticised in its elementary nature, alienated women from coal mining, Matošević concludes that if there were obstacles in women's employment, it also meant a lack of financial autonomy and the situation thus has to be understood through a prism of control and dominance (Matošević 2011: 2015-222). Following the logic of financial autonomy, but also socio-cultural determinations, I would finally suggest an inverse situation where women assume "men's" roles in becoming almost exclusive providers of the family. Nevertheless, class and nationality-based division between women workers in Rovinj, urge me to delay this conclusion. It seems that it is not employment itself but rather the nature of employment that facilitates women's emancipation.

\section{REFERENCES AND SOURCES}

Augé, Marc. 1999. Prilog antropologiji savremenih svetova. Beograd: Biblioteka XX vek.

Benussi, Bernardo. 2004. Storia documentata di Rovigno. Trst: Famia Ruvignisa.

Bosazzi, Gabriele. 2013. Rovigno d'Istria. Guida storica artistica e culturale. Trst: Famìa Ruvignisa.

Goluža, Marko. 1997. "Kako je počelo". TD magazin 2/5.

Hadar, Gila. 2007. "Jewish Tabacco Workers in Salonika. Gender and Family in the Context of Social and Ethnic Strife". u Women in the Ottoman Balkans. Gender, Culture and History. Amila Buturović and Irvin Cemil Schick, eds. London: I.B. Tauris \& Co Ltd, 127-152. 
Harding, Sandra. 2004. "Rethinking Standpoint Epistemology. What is Strong Objectivity?" $\mathrm{U}$ The Feminist Standpoint Theory Reader-Intellectual and Political Contoversies. Sandra Harding, ed. New York, London, 127-141.

Hekman, Susan. 1992. "The Embodiment of the Subject. Feminism and the Communitarian Critique of Liberalism". The Journal of Politics 54/4. [http://dx.doi.org/10.2307/2132110]

Matošević, Andrea. 2011. Pod zemljom. Antropologija rudarenja na Labinštini u XX. stoljeću. Zagreb: Institut za etnologiju i folkloristiku, Sveučilište Jurja Dobrile u Puli.

Mogorović Crljenko, Marija. 2006. Nepoznati svijet istarskih žena. Položaj i uloga žene u istarskim komunalnim društvima: primjer Novigrada u 15. i 16. stoljeću. Zagreb: Srednja Europa.

Muraj, Aleksandra. 1996. "Independence and/or Subjugation. The Ambivalence of the Social Position of Women on the Island of Zlarin". Narodna umjetnost 33/1: 135-147.

Narayan, Kirin. 1993. "How Native Is a 'Native Anthropologist'?" American Anthropologist, New Series 95/3: 671-686.

Nikolić Đerić, Tamara. 2011. “Tabachine-žene u duhanskoj industriji”. In 11. hrvatsko-slovenske etnološke paralele. Alenka Černelič Krošelj, Željka Jelavić and Helena Rožman, eds. Ljubljana: Slovensko etnološko društvo.

Sacks, Karen. 1975. "Engels Revisited. Women, the Organization of Production, and Private Property". U Toward an Anthropology of Women. Rayna R. Reiter, ed. New York: Monthly Review Press, 211-235

Škokić, Tea. 2004. "Feministička antropološka kritika. Od univerzalizma do razlike". U Između roda i naroda. Etnološke i folklorističke studije. Renata Jambrešić Kirin and Tea Škokić, eds. Zagreb: Institut za etnologiju i folkloristiku.

Vlajo, Radmila. 1999. “Tvornica duhana Zagreb”. TD magazin 1/8: 16-21.

Weeks, Kathi. 2004. "Labor, Standpoints and Feminist Subjects". U The Feminist Standpoint Theory Reader-Intellectual and Political Contoversies. Sandra Harding, ed. New York, London, 181-195.

Weeks, Kathi. 2009. "Hours for What we Will”. Feminist Studies 35/1.

\section{DUHANSKA INDUSTRIJA MIJENJA ŽIVOTE: ŽENE-RADNICE POČETKOM 20. STOLJEĆA}

Tvornica duhana Rovinj (TDR) u Rovinju jedan je od prvih industrijskih pogona na prostoru suvremene Hrvatske. Tradicija proizvodnje cigareta dulja od stotinu godina omogućila je TDR-u da se nametne na svjetsko tržište, nastavljajući uspješno poslovanje i danas. TDR je doveo i do stvaranja specifičnog društvenog i kulturnog identiteta koji prenose radnici, posebno radnice, tabacheine. Godine 1872. odlučivalo se hoće li se tvornica izgraditi u Kopru (današnja Slovenija) ili u Rovinju. Zbog mnogobrojne ženske radne snage odlučeno je da se tvornica sagradi u Rovinju. Od tada se ženska svakodnevica sasvim preokrenula. Visoke plaće i ugled koji se stjecao radom u tvornici doveo je do stvaranja nove društvene grupe. Muškarci više nisu bili jedini hranitelji obitelji, niti su bili u poziciji da biraju supružnice. Na temelju povijesnih dokumenata i intervjua s kazivačima i kazivačicama iz Rovinja i okolice, u radu se govori o razvoju i promjenama u maloj zajednici; etničke, socijalne, rodne 
razlike nastale razvojem ove industrije u radu se smještaju u širi društveno-povijesni kontekst, ujedno omogućujući usporedbu s drugim društvima u kojima se proizvode cigarete. Cilj je rada odrediti moguće kulturne i društvene obrasce ili jedinstvene primjere emancipacije žena. Nadalje, u radu se govori o važnosti različitih aspekata pamćenja, čime se upućuje na moguće idealizirane vizije prošlosti.

Ključne riječi: industrijska antropologija, duhan, žene radnice, teorija stajališta 